\title{
Jumala jälgi ajamas ${ }^{1}$
}

Ene Vainik

Teesid: Artiklis käsitletakse eestikeelse sõna jumal päritolu. Genuiinsetest tüvedest (jumm / juma, jume / jumi) tuletamise kõrval on arutluse all ka võimalik laenulisus. Varasemates käsitlustes pakutule lisatakse eesti regilauludest kogutud andmestik ning otsitakse üldmõistele võimalikke semantilisi lähtekohti naaberrahvaste (soome ning läti) mütoloogiast. Iga päritoluversiooni puhul vaetakse poolt- ja vastuargumente. Artikli lõpuosas rekonstrueeritakse arheoloogia-alasele kirjandusele tuginedes sõna jumal kasutuselevõtu arvatavad ajaloolis-kultuurilised tingimused ning ideoloogilised tendentsid. Kokkuvõttes nähakse tõepärasena võimalust, et tüvi *jumV on iidne (proto-)indo-iraani laen tähendusega 'kaksik'.

Märksõnad: eesti keel, etümoloogia, laenamine, rahvausund, semantika, teonüümid

Kus on Jumal enne käinud,

Mis tal jä̈̈nud jälgedesse?

Mis tal sattund sammudesse?

Kuld tal jä̈̈nud jälgedesse,

Hõbe tal sattund sammudesse

(H II 19, 176 (61b) < Tõstamaa khk)

\section{Sissejuhatus}

Kui ristisõdijad 13. sajandil vallutuse ja ristimisega Eesti aladele jõudsid, oli siinseil paganail juba olemas sõna jumal. Uue ideoloogilise sisuga täideti juba kaua enne käibinud sõna ja mõiste. Näiteks on see sõna üles märgitud ühes 1026. aastast pärinevas skandinaavia reisikirjelduses (SSA; Uibo 2014: 190).

Viimasel kümnendil on ilmunud käsitlusi omakeelsetest jumalanimedest (nt Sutrop 2001) ja mütoloogilistest kujutlustest, mis on eestlastele rahvus- 
romantilistel kaalutlustel omistatud (nt Põldvee 2013). Märksa vähem on aga olnud lisada sõna jumal (ja vastava üldmõiste) saamisloo enda kohta (vt nt Kulmar 2006). Käesolevas artiklis vaadatakse sõna jumal võimalikule päritolule veel kord tagasi 21. sajandil kasutada olevatele allikatele tuginedes. Kasutatud on e-keskkonnas saada olevaid ressursse: eesti regi- ja ja soome runolaulude ning etümoloogilisi andmebaase, sõnastikke ja entsüklopeediaid. Interpretatsiooni osas on toetutud ka arheoloogia-alasele kirjandusele. Eesmärgiks on koondada olemasolevaid versioone, lisada andmeid ning arutleda päritoluvariantide tõenäosususe üle.

Järgnevas esitatakse kõigepealt ülevaade senistest käsitlustest, seejärel vaadatakse regilaulude ainestikule tuginedes, millised on olnud jumala varasemad kasutused. Edasi käsitletakse selle mõiste võimalikke omakeelseid tuletusaluseid (jumm/juma, jumi /jume) ning võimalikke mütoloogilisi laenuallikaid (Jumi, Jumis, Yemo). Igale esitatud versioonile järgneb arutelu selle sobivuse üle üldmõiste 'jumal' semantiliseks lähtekohaks. Lõpuosas on üldisem arutelu selle üle, millistes ajaloolis-kultuurilistes tingimustes on selle sõna kasutuselevõtmine võinud toimuda ning millist lähteallikat võiks eelistada ajaloolise konteksti põhjal.

\section{Senistest käsitlustest}

Tarmo Kulmar (2006) toetub ulatuslikult Oskar Looritsa (1949) käsitlusele, mille kohaselt on sõna juma $(l)$ taevase üliolendi tähenduses viidav tagasi soome-volga aega. Esialgu olevat juma tähendanud 'kaant'. 'Taevase üliolendi' tähenduse saanuvat see seose tõttu hämaruse ja pilvedega, mis taevast kaanena katab ja mille varjust siis taevajumal ilmub (Kulmar 2006: 24). Kuna teise selgituse kohaselt tähendab jumi 'nägu', siis neid kahte tähendust kokku pannes saadakse väide "taevakaas on elava taeva nägu" ja seda ühendust tähistab sõna jume. Kokku tehakse järeldus, et juma (jumi) on taeva omanimi (Loorits 1949: 393 jj, viidatud Kulmar 2006 järgi).

Edasi kirjeldab Kulmar, kuidas O. Loorits eristab juma eri kasutusviise eestlastel ja soomlastel: eestlane pöördub juba muistsest ajast üttena aita, juma (aita, taevas), jumal appi (taevas appi), tere jumalime (tere taeva nimel), samal ajal kui soomlastel jääb jumi seotuks irdhinge- ja surnukultusega (Loorits 1949: 398). Kulmar distantseerib sõnas jumal esineva jum- tüve selgesti soome mütoloogias tuntud Jumist ja nn Jumi-pulmadest, mis ei näi oma sisu poolest "taevalikule üliolendile" projitseeritava suursugususega kokku sobivat. Nimelt viitab Kulmar siin Felix Oinasele, kelle järgi olevat Jumi vasaraks (Jumin kurikka) nimetatud fallost, väljend Jumi juurde magama minema tähendanuvat 
armuakti. Teiseks arvatavasti ideoloogiliselt vähesobivaks asjaoluks on see, et *jum-tüve on nn Jumi pulmadega seonduvas tähenduses peetud läti laenuks (Oinas 1981: 256-261). Sellist päritolu mööndes kaotaks sõna oma soome-ugri algupärasuse oreooli ja muutuks osaks indo-euroopa pärandist.

Oletus, et sõna jumal pole laen, vaid on tuletis genuiinsest tüvest jum-, on juba ise oma ajalooga, milles Uku Masing on toonud välja kaks koolkonda. Esimene seostab tüve tekkimise helide jäljendamisega, täpsemalt müristamisega (vt Masing 1998: 43 ja sealsed viited). Kui selle versiooni kehtimiseks vajalikud tähendusnihked ritta panna, näeks see välja nii: *jum- 'müristamine' $\rightarrow$ jum-+la 'müristamise asupaik' $\rightarrow$ 'müristaja' $\rightarrow$ 'jumal'. Teine versioon, mis varasematel aegadel on välja pakutud, ühendab sõna 'ürgtüvega, mis tähendaks 'hääd, õnne' (nt mordva jon- 'hää, mõistus, siht')" ning seetõttu jumal 'kedagi õnnelikku', mil puhul $-l$ on adjektiivi tunnus" (Masing 1998: 43 ja seal esitatud viited).

Ehkki T. Kulmar on väitnud (2006: 24), et U. Masing seostas sõna jumi taeva "palega", osutub siiski, et Masing on jumala tuletamise aluseks oleval kaksiktüvel jume/jumi toonud esile sootuks erinevad tähendused: jume tähendab 'õiget olemust' ning jumi 'lõdinat' (Masing 1998: 43). Ta tegi katset näidata, et need sõnad on omavahel seotud ja et see seos käib kuidagi surmale või surnutele viitamise kaudu: “"jumal” algselt tähendas lihtsalt surnut, kas siis animistlikult või preanimistlikult" (Masing 1998: 43). Wiedemanni sõnaraamatus (1973) esitatud väljendid jume jookseb ära kahvatumise ning jume tuleb peale punastamise kohta on pannud Masingut fantaseerima jumest kui poolisikulisest olendist või hingest, kes võib tulla ja minna, olla priske või rahulik - nii nagu inimenegi.

Mõtteseos, mille kaudu Masing jume juurest surmaga seotud tõlgenduse juurde jõudis, ei ole siinse autori jaoks kõige selgemini jälgitav: "Kui nüüd jume oleks säärane hing, siis jumal võiks tähendada seda, kellel säärane hing on oluliseks tunnuseks, kellel muid osi üldse ei ole enam, ja selle tõttu jälle tuleksime surnute juurde." Surnutega seostab Masing ka tähendust 'lõdin': "Arvatavasti oletati siis, et jume liikumisel kehas või keha pidi inimese üle jooksevad võdinad ning selle tõttu jume ning jumi võis tähendada ka seda lõdinat" (Masing 1998: 44). Tuginedes Lutsi keelesaarelt ülesmärgitud väljendile "lätt jumalihe" (loojuva päikese kohta) oletab Masing, et surnute ja surmaga seotud jumalat on lokaliseeritud asuma maa all (Masing 1998: 42). Kokkuvõttes näeb Masing mitut argumenti, mis ühendavad sõnast jume/jumi tuletatud eelkristlikku jumala mõistet surnutega: "jumal oli lahkunud jume" (Masing 1998: 44).

Seniseid käsitlusi kokku võttes võib öelda, et jumalat omasõnaks pidavad lähenemised on olnud ühel meelel selles, et see koosneb tüvest jumV (st viimane vokaal võib varieeruda (a/e/i)) ning $-l$ - ainest sisaldavast sufiksist. Eri meelt on oldud selles osas, mis on olnud tüve algne tähendus: kas 'kaas', 'nägu', 'mü- 
ristamine', 'hää', 'olemus', 'lõdin' või 'surnu', ja mis on olnud sufiksi funktsioon (kas kohasufiks või adjektiivi tunnus). Eriarvamusi on ka selles, kas tegu on algusest peale olnud just nimelt "taevase üliolendiga" või on jumal võinud elutseda ka mujal, nt maa all.

\section{Jumal}

Eesti keele seletav sõnaraamat (EKSS) määratleb sõna jumal praeguse tähenduse: 'religioonis kõrge(i)m üleloomulik olend v. jõud, keda austatakse ja teenitakse'. Etümoloogiasõnaraamat (EES) kinnitab, et see sõna on foneetiliselt ja semantiliselt praktiliselt identsena dokumenteeritud niihästi Aunuse karjala (jumal), liivi (jumāl), soome (jumala) kui isuri (jummaala) keeles. Vadja, lüüdi ja vepsa keeles lisandub tähendusele 'jumal' ka tähendus 'ikoon' e 'pühapilt'. Kaugemates sugulaskeeltes on tüve vasteteks peetud elementi jon-sõnades jondol (ersa) ja jondəl (mokša) 'välk' (jumala tuli) ning mari sõna jumo 'jumal'. Nende vastavuste põhjal on jumal identifitseeritud kui kindel läänemeresoome mordva mari tüvi (Metsmägi jt 2012: 317). Muid allikaid vaadates ilmneb, et soome keeles on jumala tähendanud ka 'nõida' või 'lausujat' (SSA). Väljendid menna ja tulla jumaloihin ning olla jumalissa kirjeldavad nõiale omast ekstaasiseisundit (love) (Vuorela 1979: 112). Paratamatult tekib küsimus, kas ka eesti keeles on jumalal olnud mingeid paralleelseid või vanemaid tähendusi.

Üheks võimaluseks midagi eesti keele sõnade varasema tähenduse kohta teada saada, on vaadata regilaulude loomult konservatiivsemat laadi keelekasutust. Järgnevas esitatakse tähelepanekud sõna jumal kasutuskontekstidest eesti regilaulude andmebaasis ${ }^{2}$. Päringuga tuli see sõna välja 2754 laulus ligi 4000 korral. $^{3}$

Sõna jumal esineb väga tihti lauludes, kus paralleelvärssides või kaugemal sisaldub ka Jeesuke, Maarja, kirik, kirikukell jms otseselt ristiusu kontekstile viitav sõna. Samas on ainult üks osa lauludest tõeliselt vaimuliku alatooniga, enamasti on kasutus ideoloogiliselt läbi põimunud talurahva argieluga, nt Jumalal oli jutik lehma, / Mariel oli maasik lehma. ${ }^{4}$ Juhul, kui laulus esineb mari, on raske aru saada, kas see on mugandus Mariast või mõeldakse mari kui regilaulude peamist lüürilist tegelast (Peegel 2004). Raske on kristlikul ja paganlikul jumalamõistel vahet teha ka kontekstides, kus n-ö väeti inimene palub abi ja toetust (kinnistunud väljendid nagu jumal hoidku, jumal sundku, jumal andku), fraasides nagu jumal su pea sugegu (lausub ema hauast vaeslapsele), jumal su kõrval magagu (kaugest kaasast mõeldes), tuo jumal jõesta jõudu (tööle minnes). Samasse ideoloogiliselt eristamatusse rubriiki kuuluvad ka stereotüüpsed tervitus- ja hüvastijätuvormelid: ait'jumal 'aitüma',jumalime 
- 'tere', jumal appi (mööduja tervitus), jumalaga 'hüvasti', jumal tuppa (mardilauludes), jumal sekka (saunarituaalis). Ka eksistentsiaalsetes hüüatustes Miks on jumal minda loonud? Kesse otsib mind ojasta (jumal), pole selge, millise religiooni jumalat mõeldakse.

Selgelt paganlikumaks võib jumala mõistet pidada lauludes, kus puuduvad viited ristiusule, selle asemel esineb see sõna loodusega seotud kontekstides. Näiteks on laule, milles viidatakse selle sõnaga tuulele: Tuule iastä, tuulekane, / Längü lännestä Jumala (H II 57, 711 (19) < Kuusalu khk), teises laulus Vii jumal viruje vihma (EÜS X 106 (31) < Jõhvi khk). Esile tuleb ka seos puudega: Jumalal on suured juured (H I 4, 136 (17) < Risti khk). Tammelaulus: Tamm siis tõusis taevassa / Oksad juureni Jumala (H II 7, 129/31 (25) < Vaivara khk). Või vastab kask abipalujale: Alt minust algu rajutenessa [---] / Juurest jookseb Jumala vett (H III 7, 289/90 (4) < Kõpu khk). Valgusnähtustega on seotud väljend jumala tule valula (H II 1, 298 (442) < Jõhvi khk) 'välgu valgel', päev läks jumalihe (E 81624/5 (3) < Setumaa) 'looja (juurde)'. Esineb motiiv jumal peitis päeva (päikese) (H IV 6, 322 (31) < Kuusalu khk), jumal tõi nooli tulitse / Et

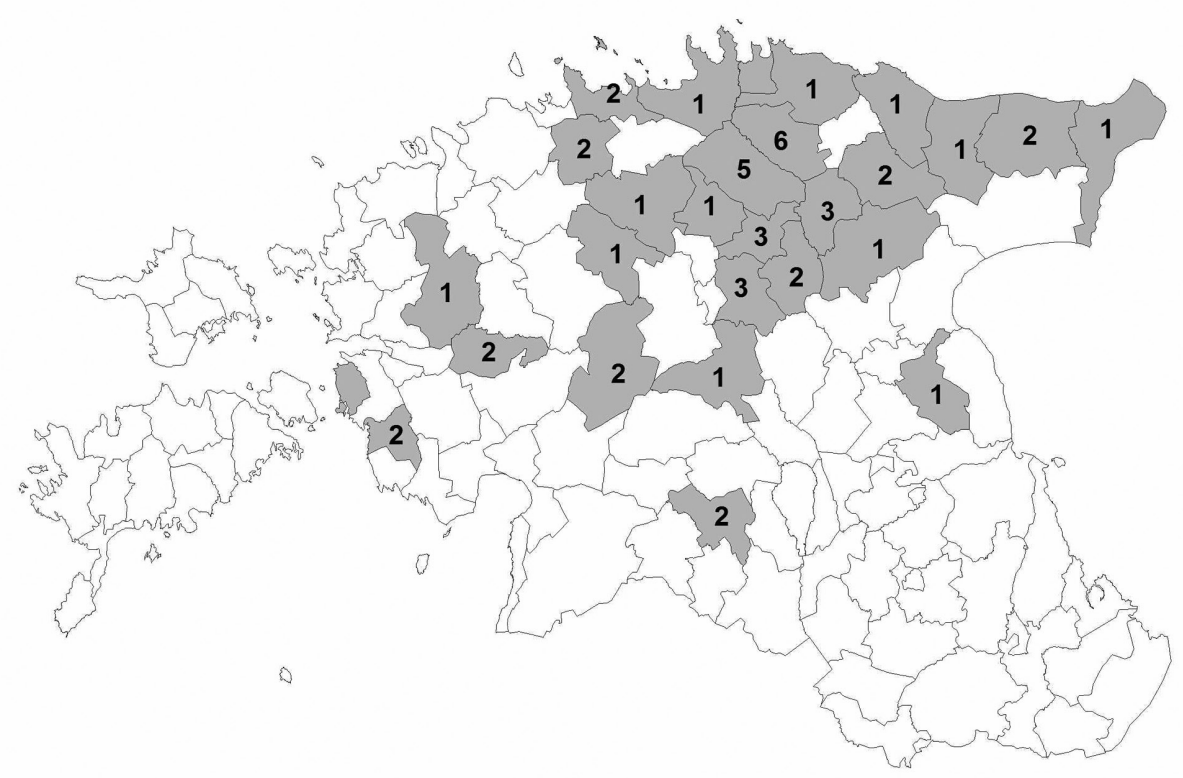

Joonis 1. Fraasi jumal jõetagune, suur jumal sootagune esiletulek. 
nii padja ära põleness'(H III 21, 441/3 (6) < Tarvastu khk). Looduskeskkonnale viitavad ka stereotüüpsed pöördumised, tihti laulu alguses: jumal jõetagune, suur jumal sootagune, peamiselt esinevad need pöördumised ühes kindlas laulutüübis ("Must mees/naine"), mis on olnud levinud Lääne-Virumaal ja sellega piirnevates kihelkondades (vt joonis 1).

Ristiusust erinevale, kuid mingil määral iseseisvale religioossete tõekspidamiste kompleksile näivad vastavat kontekstid, mida võib nimetada mütoloogilisteks, jumala mõiste esineb personifitseerituna, nt jumal-sepana Sa olid seppä ilmatarka, / Tagoja Jumalgi tarka (H II 1, 71/2 (85) < Vaivara khk). Väärismetallidega seostub nn jumala jäljerada: Kus on Jumal enne käinud, / Mis tal jäänud jälgedesse? / Mis tal sattund sammudesse? / Kuld tal jäänud jälgedesse / Hõbe tal sattund sammudesse (H II 19, 176 (61b) < Tõstamaa khk). Laulus kolmest kotkast esineb ühe olulise figuurina Jumala kukk ${ }^{5}$ (H II 4, 655/6 $(21)<$ Kodavere khk), kes ajab noori mehi ja naisi üles kauplema.

\section{Arutelu}

Regilaulud on üles kirjutatud 19. sajandil lõpul ja 20. sajandi alguses. Värsid, mida need sisaldavad, võivad aga pärineda vägagi pikast ajavahemikust hinnanguliselt alates eelrooma raua-ajast ( $500 \mathrm{eKr}-50 \mathrm{pKr}$ ) (Tedre 1998). Sellesse perioodi jääb ideoloogilises mõttes nii paganausu aega, katoliiklust, luterlust kui ka vennastekoguduse mentaliteeti. Kui eeldada, et just mittekristlikus kontekstis esinevad sõna jumal kasutused pärinevad vanemast ajast või esindavad ideoloogiat, mis on ajaliselt kas vanem või paralleelne kristlusega, siis just nendest kontekstidest tasub otsida selle sõna võimalikke vanemaid tähendusi.

Märkimist väärib muidugi jumala mõiste seostamine loodusnähtustega (tuul, puud, valgus). Üks valgusega seotud motiividest - päikese peitmine on kindlasti mütoloogilise tähendusega ning levinud lisaks läänemeresoome folkloorile ka balti pärimuses (Laurinkienè 2004). ${ }^{6}$ Viited metallitöötlemisele ning kulla ja hõbeda mainimine osutavad nende metallide, nende omanike ja käsitlejate kõrgele staatusele. Kokkuvõtlikult on regilauludes võimalik märgata jumalakäsituse eri kihistusi loodususkumuslikust panteismist mingit laadi omamütoloogiani ning teisalt läbipõimumist ristiusu poolt kultiveeritud käsitusega ja naaberrahvaste mütoloogiast pärit motiividega. 


\section{Võimalikke semantilisi lähtealuseid}

\section{jumm/juma}

Eesti keele seletavas sõnaraamatus sõna jumm puudub (EKSS). F. Oinase (2004) väitel on see sõna Pärnumaal tähistanud ühest otsast kokku seotud linakubu. Jumm, juma tähendavat eesti murdeis ka 'mõhna, muhku, paiset kehal' ja 'pahka, väärmoodustist puul' (Oinas 2004). Viimane tähendus leidub sõnal juma tõesti ka Saareste (1958-1979) sõnaraamatus (3: 309). Murdesõnastiku $(\mathrm{EMS})^{7}$ põhjal võib täpsustada, et sõnal jumm on murretes mitu tähendust: 1) 'lühike, ümar ja jäme asi v olevus: jupp, junn, tükk; sõlm; klomp; pundar' nt palgi jumm; 2) 'puuriida risti laotud ots'. ${ }^{8}$ Need samad tähendused on teatud taimenimetuse (perekond Centaurea) kõrval ka sõnal jum(m)ikas.

Kuigi EES peab tüve jumm-/juma- (tuleb esile nt sõnas jumikas) häälikuliselt ajendatuks, on tähelepanuväärne, et vähemasti 'puunoti' tähendustes leidub vaste ka vene keeles: ю́мла, 'ujuv puit', 'omavahel ühendatud parvede rodu'. Selle, vene etümoloogidele tundmatu algupäraga sõna levik on olnud piiratud oluliste veeteede ääres paiknevate Novgorodi ja Tšerepovetsi ümbrusega. Koola poolsaarelt on registreeritud ю́ма tähenduses 'laplaste kogunemine kalasaaduste müügiks'. Tähendust 'puuriida ristilaotud ots' saab aga seostada samuti vene keeles leiduva sõnaga юл 'virn, rida põletatud telliseid'9 (Vasmer $1958^{10}$ ).

\section{Arutelu}

Kuigi esmapilgul näib, et tähendusel 'puunott' ei ole mingit tegemist abstraktse jumala mõistega, olgu siin esitatud mõned võimalikud seosed. Esiteks nägime eelmises alajaotises, et regilauludes seostus üks n-ö paganlikumaid ja looduslähedasemaid jumala kasutamisi puudega (jumala juured, kasemahl kui jumala vesi). Teiseks, nagu väga hästi teada ja sageli tsiteeritud, kirjeldas Läti Henrik, kuidas paganlikud eestlased austasid puuslikke, st puidust jumalakujusid, ning panid imeks, kui nendest maharaiumisel verd välja ei voolanud (HLK 1993: 155). ${ }^{11} \mathrm{Ka}$ artikli alguses osutatud sõna jumal kirjalik esmamainimine on aset leidnud just puukujudega seotud kontekstis: Karjalaste maal oli pühas metsas Jomalin kuvapatsas 'jumala kuju' (SSA). Kirjalikest allikatest on leitud ka hilisemaid jälgi eestlaste puidust jumalakujudest (Sutrop 2004b). Seega ei tohiks lihtsalt niisama kõrvale heita varianti, et mõiste jumal on abstraheeritud näiteks mingi konkreetsema iidoli või iidolite puidust representatsioonide põhjal. Selles ei oleks midagi loogikavastast.

Kuivõrd aga sõnal jumal on olemas samatähenduslikud vasted ka lähemates ja pisut kaugemates sugulaskeeltes (EES), ei saa see abstraheerimine olla 
juhtunud eesti keeles, vaid on pidanud aset leidma palju varem - perioodil enne läänemersoome ning mordva ja mari keelte lahknemist (Metsmägi jt 2012: 317). Eelpool esitatud vene keelest leitud tundmatu päritoluga vaste võib osutuda substraatsõnaks, kuid on vähemasti praegusel tõendatuse tasemel liiga nõrk argument, väitmaks et läänemeresoome-mordva-mari oletatavas algkeeles üldse vastav 'puunoti' lähtemõiste olemas oli. Seega ei saa midagi kindlamat väita ka võimaliku abstraheerimise kohta. Samas ei saa sellist tähenduse kujunemist täielikult välistada.

\section{jumiljume}

Tänapäeval on sõna jume tähenduseks 'näovärv, (näo)ilme' (EKSS). See tüvi osaleb ligi kahekümne tuletise ja liitsõna moodustuses (Vare 2012), mis kõik on seotud inimese näo vaadeldavate omadustega (jumekas, jumestama, jumestuskunstnik jne). Koondkorpuses ${ }^{12}$ esineb sõna jume 1354 korda. Sagedasemad on positiivsed täiendid, nt terve, hea, loomulik, ilus, värske, ühtlane, särav, kaunis, rõõsk, veatu, suvine, klaar, kena jne. Leidub vaid mõni negatiivse varjundiga iseloomustus: kahvatu, kollakas, haiglane. Selline esiletulek osutab, et näo visuaalne kvaliteet on väga oluline positiivsuse näitaja. Korpuse materjalist tuleb välja ka paar kinnistunud väljendit, millega kirjeldatakse mitte näovärvi, vaid abstraktsemate nähtuste positiivsust: millelgi (nt mõttel, ettepanekul, asjal) on jumet st see 'on paljutõotav' ja miski (nt juurdeehitus, plaan, koostöö) hakkab jumet võtma st sellest hakkab 'asja saama'. Asta Õimu fraseoloogiasõnastikus (2000) on need väljendid samuti registreeritud - tähendustega vastavalt 'ilmet olema' ja 'ilmet võtma'. Kokkuvõtikult on jume tänapäevases pruugis miski, mille järgi me otsustame inimese või ka ideede ja ettevõtmiste üle - kas nad on meie silmis ligitõmbavad või mitte.

Etümoloogiasõnaraamat (EES) ütleb sõna jume kohta, et tegu on läänemeresoome tüvega, millel on vasted soome murretes ja vadja keeles (jumõ 'nägu'). Võimalikuks on peetud laenamist eesti keelest soome keelde. Murdesõnastikus on sõnal jume kolm peamist tähendust: 1) näovärv; (näo)ilme; terve välimus (ka looma kohta), 2) värv, värvitoon, -varjund, 3) judin, võbin (EMS) (vt joonis 2). Lisaks on registreeritud ka adjektiiv jume (g - $d a$ ) 'jumekas'. Tüve jumi murdesõnastikus eraldi märksõnana ei esine, küllalt on seal aga tuletisi sellest tüvest. Leidub ka üks obstsöönse alatooniga liitsõna - jumikara 'jääpurikas' (EMS).

Eesti regilaulude andmebaasis andis päring jumi*/jume* tulemuseks esinemise 119 laulus. Tüvevariandid jumi ja jume esinevad paralleelselt samades sisulistes kontekstides, jumi saab esile tulla ainult seal, kus ta on nimetavas käändes, st subjekti positsioonis. Lisaks sellele esines veel 43 laulus tuleta- 


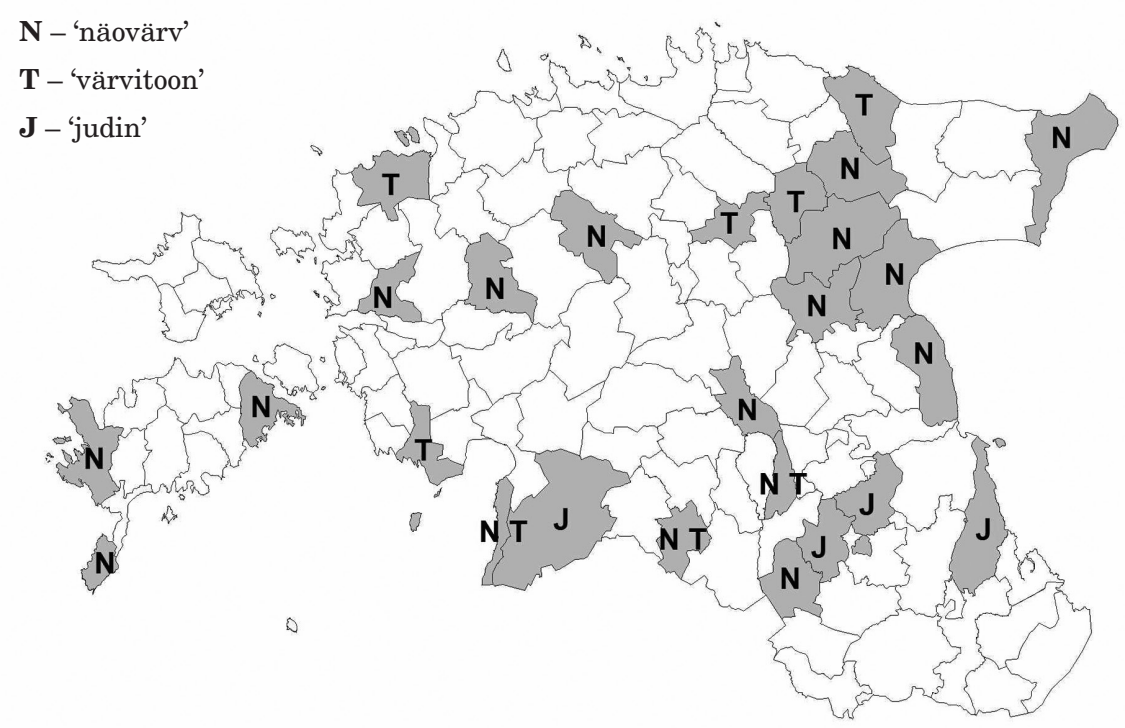

Joonis 2. Sõna jume tähenduste esiletulek eesti murretes.

tud tüvi jumika*. Viimased, st jumikale kui konkreetsele taimele (perekond Centaurea) viitavad tekstid on järgnevast analüüsist kõrvale jäänud, kuivõrd esindavad kõik üht ja sama populaarset motiivi jumika juurte kündmisel terveks jätmisest kiusuna härra või peremehe vastu. Kui ka lõppriimilised ja omaloomingulisena märgendatud tekstid kõrvale lükata, jääb sõelale106 regivärsilise rahvalaulu teksti, milles jumi ja jume esinevad kokku 113 korral. Kõige rohkem neid sõnu sisaldavaid laule on kirjutatud üles Karksi, Halliste, Kolga-Jaani, Paistu, Tarvastu ja Viljandi kihelkonnas (vt joonis 3), st ajalooliselt Mulgimaalt.

Regilauludes esineva (enamasti alliteratiivse) konteksti põhjal on võimalik välja abstraheerida järgnevad tüve jume/jumi korduvalt esile tulevad tähendused: 'elujõud', 'vaimujõud', 'näovärv' ja ‘judin'. Kõige rohkem eri tähendusi tuli esile Hallistest kogutud ainestikust (vt joonis 4). Samalt kaardilt on ka näha, et geograafiliselt kõige laialdasem on olnud jume/jumi esinemine kontekstides, kus ta tähendab elujõudu. Enamasti seostub see levik aga kindlate kinnisvormelite või isegi kindlate laulutüüpide levikuga. 


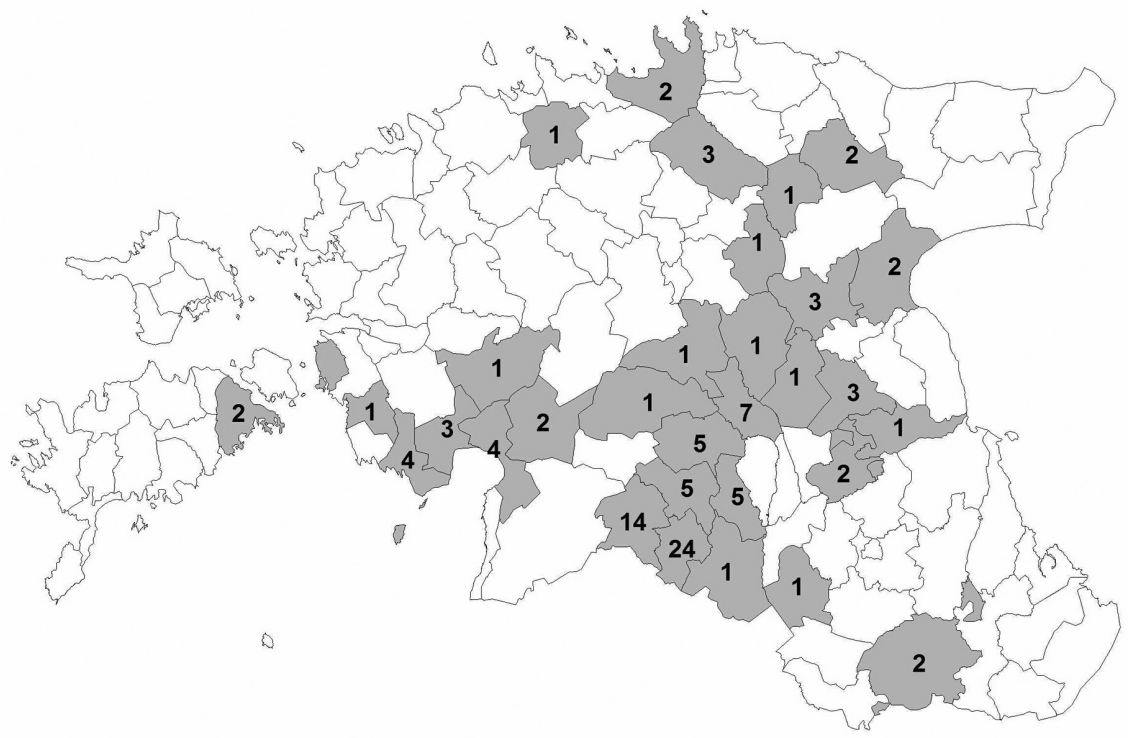

Joonis 3. Tüve jumi/jume esiletulek regilauludes.

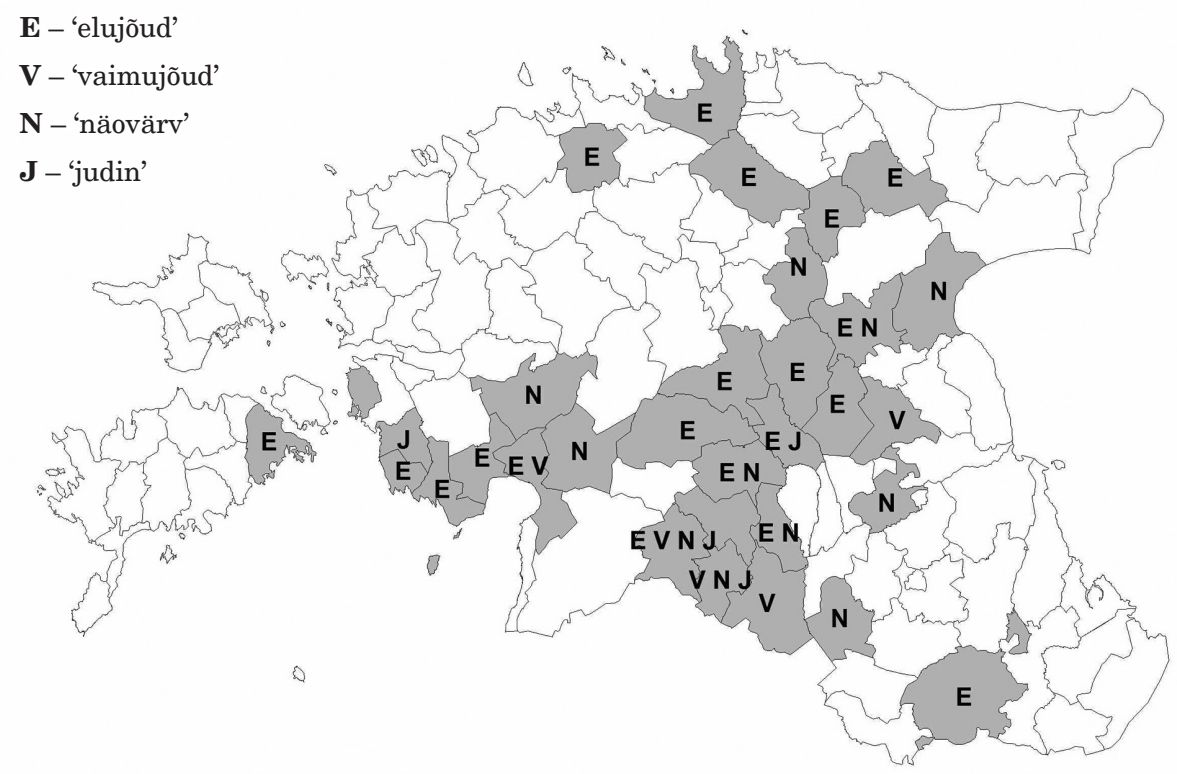

Joonis 4. Tüve jumi/jume eri tähenduste esiletulek regilauludes. 
Tähendust, mida olen siin nimetanud "elujõuks", võiks nimetada ka "elumahlaks", kuna enamasti esineb ta seoses joomisega. Kõige sagedasem ( $\mathrm{N}=26)$ on keelav fraas Ärge sööge mu südant, ärge jooge mu jumet!, millega laulik palub ennast säästa. Sellega võivad pöörduda neiud noormeeste poole (nt poisikesed, roosikesed) ja vastupidi (nt Viru vitid, Harju hakid, Viru naised vimmas-seljad). Mis on olnud selliste pöördumiste funktsioon, pole päris selge, kuid arvata võib, et tegemist on mingit sorti tõrjemaagilise vormeliga, kuna sama fraas esineb ka ussisõnades (nt H III 4, 163/4 (2) < Ambla khk). Linakitkumise või lõikustöö kontekstis kujutatakse kurnavat tööd üsna kujundlikult põllu ääres aset leidva jume joomise ning vere servamisena: ${ }^{13}$ Otsan juudi sääl jumeda / Veeren verda serväti (EÜS XII 693/7 (12) < Paistu khk). Elujõule (selle vähenemisele) viitab vähemasti seitsmes kihelkonnas üles kirjutatud "Müüdud neiu", milles jumi esineb paralleelvärssides ning paralleelses tähenduses sõnadega vägi ja kangus: Mul jäi jume puie peale, / Mul jäi vägi välja peale, / Mul jäi kangus karja teele (H II 41, 711/3 (5) < Tõstamaa khk). Siin kujutatakse jumet mitte otse vedelikuna, vaid mingi abstraktsema substantsina, mis võib inimesest välja loodusesse "lekkida". ${ }^{14}$ Elujõu (selle taastamise) tähendusega seostub ka jume kasutamine adjektiivina tähenduses 'kosutav', nagu näiteks värssides Mull om kollmi allikuda / Üits jooseb vetta Tõine metta / Kolmas jume õluta (H II 55, 295/6 (22) < Tarvastu khk) ning verbitüvena tähenduses 'kosutama', nt fraasis joo karja / jumeta karja (H II 43, 407 (23) < Suure-Jaani khk).

Ülalesitatud "elujõu" tähendus seostub organismi füüsilise seisundiga: puhanud oleku, tervise, söönud ja joonud olekuga. Kui inimene või ka loom on jumes, siis on ta priske ja hea tervise juures, see on kurnatuse ${ }^{15}$ vastand. Füüsilise elujõu kõrval on seda sõna kasutatud aga ka psühholoogilise tervise ja vastupidavuse kohta, mida võiks kirjeldada sõnadega vaimujõud või meelekindlus.

Tähendus "vaimujõud" on põhiliselt abstraheeritud korduvalt (24) esile tulevast fraasist jumi jookseb. Siingi on domineeriv keelav fraas ära lase jumel joosta, mis on mõeldud julgustusena kosja minejale, enamasti järgnebki otsene julgustus: Hoia jumi julgesti. Meestest eeldatakse, et nad suudavad jumet mingil määral kontrollida (st olla julged ja otsustavad): Meeste jumi julge'emba (H III 9, 238 (2) < Torma khk). Naistegelastega seotud kontekstides aga kirjeldatakse vaimujõu (meelekindluse) kadu, nt Juba võt's mul jumi joosta / Jumi joosta veri veerta / Kudas vii vere veele / Lase armu allikusse (E, StK 15, 157/9 (111) $<$ Karksi khk). Ka 'vaimujõu' tähenduses on jumi kujutatud mingit laadi vedelikuna, selle kadumine näost tähendab "loogiliselt", et ta vajub kehas allapoole: Veri varvuni vajuksi / Jumi kannuni kaoksi (H I 7, 249/50 (14) < Viljandi khk). Levinud laulutüübis "Mehetapja Mai" sajatatakse jumi maa sisse jooksma nii nagu teevad seda haavapuu juured (mõnes teisendis ka vastupidi). Vedelikuna kujutamise kõrval on jumet vaimujõu tähenduses ajuti ka personifitseeritud, 
nt Miil küll mõtleb mõisa poissa, / Jumi kutsub kutserida (H II 58, 800 (51) < Pilistvere khk). Minekul o meie meele / kõnnikul o meie kõne / jooskemen o meie jume / astakul ole süäme (E 45662 (29) < Karksi khk).

Tähendus "näovärv" on abstraheeritud kontekstidest, milles sõna jume lähiümbruses leidub teisigi visuaalsele vaadeldavusele viitavaid sõnu. Näiteks laulus “Tuul puhub”: Mi’ nü̈̈d puhub tuulekene / Või nü̈̈d lõotsub lõhnakene / Puhud sa näiu punada / Juud sa näiu jumeda / Võtad verda palge'esta / Juud jume huulilt punasilt (H III 9, 238 (2) < Torma khk). Uuemates, riimilistes rahvalauludes on 'näovärvi' tähendus juba domineeriv, nt Ma võida poisid punala / Isandad võidan ilula, / Junkurid võidan jumela H II 55, 565 (9) < Paistu khk). Tähendust 'judin' tuli esile ainult paaril korral sama laulu teisendites, kontekstis, kus kositu ei julge oma nõusolekut kohe välja öelda: Jumi juusis üle ihu (H III 14, 773 (25) < Kolga-Jaani khk).

\section{Arutelu}

Kuigi tänapäeva keeles on jume tähenduseks 'näovärv' ja sellega seostuv atraktiivsus ning visuaalsele aspektile viitavad ka murdesõnastikus esitatud tähendused, osutab regilaulu kontekstide analüüs, et varasemal ajal on selle sõna tähendus olnud siiski midagi enamat kui pelk 'näoilme' või '-värv' - see on tähendanud ka 'elu- ja vaimujõudu'. On ilmne, et vere juurde- või äravool näost on olnud oluline signaal organismi füüsilise ja psühholoogilise seisundi kohta. Kui valiti nt elukaaslast või ka tööjõudu, siis oli selliste märkide tundmisest kindlasti kasu. Mingil moel on seos näovärvi ning elujõulisuse vahel esindatud ka tänapäevastes kinnisväljendites jumet olema ja jumet võtma hakkama.

Kognitiivses keeleteaduses käibiv nn kehapõhisuse hüpotees ennustab, et abstraktsemate nähtuste mõistestamine toimub tuginedes kehapõhisele ja kogemuslikule ja mitte vastupidi (Lakoff \& Johnson 2011; rakendusi nt Sweetser 1990; Vainik 2013). Seega peaks kehalise kogemusega seotud tähendused, nt 'näovärv' või ‘judin' olema igal juhul primaarsemad kui abstraktsed 'elu-' ja 'vaimujõu' tähendused. Siin on olemas täiesti loogilised tähenduse ülekandmise viisid: tähendust 'näovärv' saab kasutada 'elujõule' või 'vaimujõule' viitamiseks metonüümsete (pars pro toto) ülekannete abil KAHVATUS ESINDAB HAIGUST/HIRMU ning PUNA ESINDAB TERVIST/ULJUST. Esitatud näidetest nähtus ka, et abstraktsema nähtuse mõistestamiseks oli kasutusel konkreetsem - vedelik: võis sedastada mõistemetafoore ELUJÕUD ON VEDELIK ning VAIMUJÕUD ON VEDELIK. Samuti tuli ette personifikatsioon VAIMUJÕUD ON ISIK. Nende kognitiivsete projektsioonide näol on olemas kõik komponendid, et saada nii isikustatud 'elususe' e mingit laadi 
jumaluse kui ka vedela 'elususe' e mingit laadi elueliksiiri mõisted. Ainestikus leiduski ka väljend poolik puhast jumet (tähenduses 'piiritus').

Teisalt sobib tähendus 'elujõud' ideaalselt kokku Looritsa (1990) kirjeldustega selle kohta, kui obsessiivsed olid vanad eestlased elujõu suhtes: seda usuti olevat looduses, inimese ja loomade südames, suguelundites, veres, higis, juustes, küüntes, hammastes, jälgedes, varjus, hinguses jne. Siinsed leiud regivärssidest nagu jume joomine ja teise jume jooksma sajatamine sobivad hästi kokku ka elujõu ülekandmise kontseptsiooniga, mis vanadele eestlastele omane olnuvat: seda võis kas omandada ja kaotada, hankida endale ja anda teistele, võis suurendada ja vähendada, süüa ise ja sööta teisele, siirda ühest kohast mehhaaniliselt teise, ühelt kehalt teisele. Ühel kehal võis olla enam hingejõudu kui teisel: täiskasvanuil enam kui lastel, meestel enam kui naistel jne (Loorits 1990: 7-12). Ka teised uurijad on sõnal jume/jumi näinud kohta just eestlaste mentaalses maailmapildis sõnade jumal, vaim, hing ja meel kõrval (nt Sutrop 2004a).

Seega osutub tüvi jumi/jume tähendusega 'elu- ja vaimujõud' olevat igati põhjendatud semantiline alus jumala mõiste tuletamiseks, seda nii kognitiivsete ülekannete seaduspärasusi kui rahvauskumuslikke tendentse arvesse võttes. Näiteks eelpool välja toodud sõna jumal kasutuskontekstidest regilauludes viitavad jumalale kui elu- ja vaimujõu valdajale need, milles väljendub jõu, abi ja toetuse palumine (nt jumal hoidku,jumal sundku,jumal andku ja pöördumine Tuo, jumal, jõesta jõudu). Probleemiks on, et see tähendus tuleb regilauludes esile geograafiliselt üsna piiritletud Eesti osas - ajaloolisel Mulgimaal. Oleks raske seletada, kuidas on sellisest lokaalsest tähendusest kujunenud üldmõiste jumal saanud levida sugulaskeeltesse. Samuti on regivärsside andmestikust näha, et tähendus 'elu- või vaimujõud' on geograafiliselt laiemalt levinud kui 'näovärv' (joonis 4). Viimane tähendus on enam tulnud esile alles riimilistes rahvalauludes, st hilisemas kihistuses. Selline ajaline ja arenguline järgnevus on aga täpselt vastupidine sellele, mida ennustab kehapõhisuse hüpotees.

\section{Jumi}

Võimaluse kõrval, et jumal on tuletatud apellatiivist, ei tuleks siiski rutata kõrvale heitma ka võimalust, et see on saadud mõne mütoloogilise tegelase pärisnimest. Eesti ainestikust ei ole Jumi-nimelist jumalust teada, välja arvatud Felix Oinase väide, et kohanime Juminda varasem kuju on Jumintake ( $<*$ Jumin takana). Seda on ta seostanud soomemõjulise Jumi-kultusega (Oinas 1981: 256). 
Soome rahvapärimuse kohaselt on Jumi üks vanakurja poegadest, pime paharet, kes inimesi ja loomi umbropsu vibuga laseb, kutsudes sellega esile ootamatuid haigestumisi. Jumi noole tabamuseks (Juminampuma) on nimetatud kühmu, muhku (olgu siis inimesel, nt koeranaela, või pahka puul) (Vuorela 1979: 112). Looduses leiduvaid kühme ja püstisi kive on kutsutud Juminkeko 'Jumi kuhi'. Mõistatustes ilmneb Jumi omadus kõikjal kohal olla. ${ }^{16}$ Teisest küljest on Soomes Jumit peetud ka abieluõnne edendajaks. Nn Jumi pulmadeks kutsuti Soomes mängupulmasid - noorte tantsupidusid ühise magamisega -, mida on seostatud abielu-eelse ja -välise seksiga (Vilkuna 1974). Näiteks leidub Soome runolaulude andmebaasis ${ }^{17}$ selline: Jummin ukko, Jummin akka, /Jummin entinen eläjä, / Meni apumäjelle, / Apumäjen kukkulal / Heilutteli helmojaa / Häilyttel helmojaa / Tuost tyyty, tuost täyty, / Tuost paksuks paneks / Lihavaks liitelie jne (< SKVR IV3 4378). Üldiselt vähemasti 18. sajandil ei olnud neil pidustustel ühismagamine enam tavaks, pigem on mängupulmade raames kogutud andameid kaasavarata tütarlastele (Sarmela 1994: 262-263). Mõned uurijad on Jumi pulmasid seostanud varasemal ajal praktiseeritud viljakusriitustega, kus on pruute n-ö "proovitud". On ka teateid sellest, et Lapis olevat Jumit veel 17. sajandil austatud kui endi ja soomlaste esiisa (Oinas 1973).

\section{Arutelu}

Kokkuvõtes ilmub Jumi kasutada olevate kasinate teadete kohaselt kahepalgelisena - tema poolt on olnud karta nii ootamatut ebaõnne kui ka loota viljakust ning edenemist. Ei tundu võimatu, et selline tegelane võib olla üldistunud kandma laiemaid "üliolendi" funktsioone. Soome Vikipeedia artikli kohaselt ongi Jumi soome-ugri keeli kõnelevate rahvaste nimetus üleloomulike nähtuste kohta, panteistliku maailmahinge nimetus. On esile toodud, et mari keeles esineb see kujul Jumo. ${ }^{18}$

Eespool kokkuvõetud sõna jumal kasutuskontekstidest eesti regilauludes saab Jumi atribuutikaga (vibu ja nool) seostada üksnes värsirida jumal tõ $i$ nooli tulitse. Võib mõtiskleda ka selle üle, kas pöördumine jumal jõetagune (mäetagune, sootagune) laulutüübis "Must naine/mees" ei pärine mitte mingist mängulisest traditsioonist. Ka värsid ärge sööge mu südant, ärge jooge mu jumet olid võrdselt adresseeritud nii noormeestele kui neidudele. Pole võimatu, et need lähtuvad mingist Soome Jumi pulmadega analoogilisest mängupulmade tavastikust. Ka eesti murdeainestikus säilinud väljend jumikara 'jääpurikas' oleks nagu heiastus Jumi seosest viljakusega. 


\section{Jumis}

Sõna jumis (juma ja jume on vastavalt nais- ja kesksoo vormid) tähendab läti keeles omavahel kokkukasvanud puuvilju, pähkleid, seeni, viljapäid jne. Läti etümoloogiasõnaraamatu kohaselt tuleneb läti jumis indo-euroopa tüvest *ieu: *iu- 'köitma, kokku siduma' (sama tüvega on nt sanskriti yamah 'kaksikud'). Jumise algseks tähenduseks peetakse tähendust 'kokkuseotud', kuid on pakutud ka 'kaheharulist oksa'19 (Karulis 1992: 361).

Tähendus 'topeltpuuvili' esindab loodususkumuste kohaselt seost esivanematega, personifitseeritud Jumis aga kujutab endast ühte indoeuroopa mütoloogia pühadest kaksikutest (Karulis 1992: 361). Kinnisväljendites esineb ka samast tüvest saadud tuletis jumala, millega viidatakse paksule naisele või lehmale. Sellel tuletiseks peetud sõnal leidub aga samuti vaste nii sanskritis yamala 'paarikaupa, kahekordselt' kui ka praakritis yamala- 'kaksikud' (Karulis 1992: 361). Võib oletada, et ka läti jumala kui 'tavalisest paksem naine või lehm' on seostunud just kaksikute kandmisega. Selle sõna rahvaetümoloogiliseks seletuseks on aga kujunenud 'Jumise abikaasa' (Karulis 1992: 361).

Läti rahvatraditsioonis on Jumist austatud kui vilja- ja viljakusjumalust, kelle atribuudiks on topeltvili ja teda sümboliseerib ristatud vilja- (või hobuse)peade kujutis (vt joonis 5). Selline sümbol katuse kaunistusena usutakse toovat õnne. Jumise austamise pidustused (Apjumibas) on toimunud sügisesel pööripäeval pärast saagi koristamist, sellega avatakse sümboolselt talve väravad. Järgmise aasta viljasaagi tagamiseks sooritatav Jumise püüdmise rituaal tähendab seda, et sõlmitakse viimane veel põllul kasvav punt vilja puntraks ja keeratakse ots allapoole, kinnitades seemikud maasse. Hiljem punutakse samast viljast laulude saatel pärg ning antakse see talveks hoiule kas pruudi või mõne kogukonnas üldiselt austatud naisterahva kätte, kes sellest pärjast saadavad seemned kevadel esimesena maha külvab. Pidustuste osa on ka uudseviljast tüseda Jumise pätsi küpsetamine. ${ }^{20}$

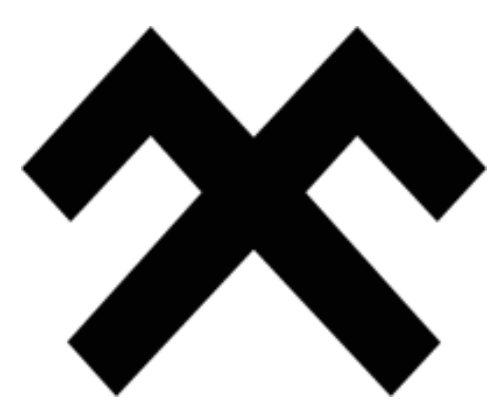

Joonis 5. Üks enamlevinud variatsioone Jumise sümboolsetest esitustest. 


\section{Arutelu}

F. Oinase arvamuse kohaselt on topeltviljast saanud viljakusjumalus sellises puuviljas või juurviljas kätkeva hüperenergia tõttu. Sellise vilja söömine soodustab pärimuse kohaselt kaksikute sündi (olgu siis naisel või loomal). Topeltviljasse kätketud jõud, nagu püha jõud üldse, võib teha nii head kui ka halba. Topeltviljapea leidmine võib ennustada peatset abielu, aga ka surma ja matuseid (Oinas 2004). On märgatud paralleele Läti Jumise kultuse ja Soome Jumi-pulmade vahel. Kummaski rahvatradistioonis tuleb ette mingit laadi "paaris olemise" või "paari panemise" motiiv, mis esindab viljakust - olgu siis põlluviljeluses või abielu alal. Samuti on mõlemas rahvatraditsioonis sel olendil ka oma tumedam külg, mis ennustab haigusi ja õnnetust. Kuigi eesti keeles sõnatüvel jum- selline paarsustähendus teadaolevalt puudub, oletab Oinas, et Läti Jumis on rännanud Soome ja Lapimaale just Eesti kaudu (Oinas 2004).

Kokkuvõtteks: meie lähinaabreil on olemas sõna jumis, mille nais- ja kesksoo vormid langevad häälikuliselt kokku tüvedega juma ning jume, ning tähenduse poolest on see sõna olnud mütoloogilise sisuga. Tuletada sellisest semantilisest ja foneetilisest alusest üldnimi jumal tundub ülimalt tõenäoline. Veelgi enam, läti keeles on olemas olnud ka sõna jumala 'paks emane', millest ei peaks isegi mitte midagi tuletama, vaid mis on võidud võtta eestikeelsesse käibesse lihtsa sõnalaenuna. Funktsioon võib olla üldistunud spetsiifilisemalt viljakuse edendamiselt üldisemale heaolu tagamisele ja kaitsefunktsioonile. Selle funktsiooni olemasolu eesti varasemas jumalakäsituses on tuvastatav näiteks artikli esimeses osas kirjeldatud kinnisvormelite (ait'jumal 'aitüma', jumal appi, jumal tuppa, jumal sekka) põhjal.

Taas on kirjeldatud semantilise ja foneetilise lähtevormi probleemiks lokaalne levi Lätis (võimalik, et ka Eesti-Läti kontaktalal). Selleks, et olla laenatud läänemeresoome (ning mordva ja mari) keeltesse, peab laen olema märksa vanem - pärinema kas balti laenude või isegi varasemast indo-iraani laenukihistuse perioodist.

\section{Yemo}

Läti Jumise juurest läheb katkematu seos indo-euroopa mütoloogia pühade kaksikute juurde: läti jumis 'kaksikvili' on tagasiviidav protobalti rekonstrueeritud tüvele *jum-, mis on tähendanud 'kaksik'. ${ }^{21}$ Rekonstrueeritud proto-balti tüvi on omakorda seostatav alg-indoeuroopa tüvega *yem- 'kaksik' (vasted on vanaindia yamá- 'kaksik' ja Avesta yə̄ma 'kaksik'). ${ }^{22}$

Kaksikutest veel algsem näib olevat tähendus 'koos hoidma, kokku köitma', vähemasti Pokorny sõnaraamat (2002) esitab sõna *iemo- 'kaksik' kui tüve iem- 
'koos hoidma' tuletist. Võimaliku tuletisena samast tüvest on ära toodud ka muinasnorra hermafrodiitse jumaluse nimi Ymir. Mingis mõttes on võimalik, et siin "ring sulgub" ja et algindoeuroopa tähendusega 'kokku köitma' on seostatav ka artikli algupoolel jummi vastena välja toodud vene ю́мa, 'ujuv puit', 'omavahel ühendatud parvede rodu'. ${ }^{23}$

Indoeuroopa loomismüüdi kohaselt olid aegade alguses kaks venda, ühe nimi oli Manu (sellest tüvest tulevad inimest tähistavad sõnad nt inglise man, saksa Mann, vene муж jne) ja teise nimi oli Yemo 'kaksik'. Selleks, et tänane maailm saaks sündida, pidi Manu ohverdama Yemo, kelle tükkidest said erinevate taevajumalate soosingu toel tuul, päike, kuu, maa, tuli ning erinevad seisused. Yemo vasteteks on peetud jumalusi eri kultuurides: India Yama, Avesta Yima, Norra Ymir, võimalik et ka Rooma Remus < *iemus 'kaksik' (Anthony 2007; Puhvel 1996: 285-290). Näiteks India mütoloogia Yama on surma isand. Kuivõrd tema oli esimene surelik jumalus, kandub see omadus kõigel elaval edasi põlvest põlve. ${ }^{24}$ Yama on vedade kohaselt olnud lõunasuuna ja surnud esivanemate heasüdamlik valitseja. ${ }^{25}$ Hilisemates mütoloogilistes arengutes on talle lisandunud kohtumõistja roll.

\section{Arutelu}

Eelnevat kokku võttes on mitmetes indoeuroopa traditsioonile toetuvates kutuurides olemas vaste mingile elu ja surma paratamatut dialektikat esindavale jumalusele, keda on kõige loomulikum olnud kujutleda kaksikute mõistet appi võttes. Kuivõrd indoeurooplus on olnud karjakasvatajate kultuur, olid nad kahtlemata ülihästi kursis nii kaksik-järelkasvu heade külgede kui ka võimalike ohtudega. Pole selge, kas eesti sõna jumal ning selle läänemeresoome ning mordva ja mari vasted võiksid olla seotud selle tüvega, kuid vähemalt üks kord on see tüvi soome-ugri keeltesse laenatud, saami keeles on olemas sõna juomek 'kaksik' ${ }^{26}$ Samuti väärib tähelepanu, et artikli algusosas välja toodud rahvalaulukontekstides tuli jumal esile seoses nii tuule, tule kui päikesega, mis kõik osutuvad indo-euroopa loomismüüdi kohaselt olevat Yemo tükkidest tekkinud. On võimalik, et meiegi varasem panteistlik jumalakäsitus on osaliselt olnud mõjutatud neist müütidest.

\section{Üldine arutelu ja kokkuvõte}

Nagu eelnevast nähtus, leidub tüvel jum- õigupoolest mitmeid võimalikke tähendusi, millest sõna (ja mõiste) jumal võib olla tuletatud ja/või laenatud. Mitmeid on välja pakutud juba eelmise sajandi käsitlustes, nt 'kaas', 'nägu', 
'müristamine', 'hää', 'olemus', 'lõdin' ja 'surnu'. Käesolevas artiklis käsitleti selle tüve variantide tähendusi 'puunott', 'näovärv', 'elu- või vaimujõud' ning võimalikke mütoloogilisi lähteallikaid Jumi (soome pime ambuja-paharet), Jumis (läti viljakusjumalus), Yemo (indo-euroopa mütoloogia püha kaksik).

Kuivõrd paeluvad ja eestlaste arhetüüpse elujõu käsitusega (Loorits 1990) kokkusobivad meile ka ei tunduks seosed tüvega jumi/jume tähenduses 'eluja vaimujõud', tuleb see versioon vist kõrvale jätta, kuna tegu paistab olevat suhteliselt hilisema ja lokaalse tähendusülekandega. Samuti tuleb esialgu sugulaskeelte andmete puudumise tõttu kõrvale jätta versioon, mille kohaselt on jumala mõiste seotud puust jumalakujude kummardamisega ja oleks seega tagasiviidav tähendusele 'puunott'. Läti Jumis ning soome Jumi sobivad oma mütoloogilise sisu poolest. Problemaatiliseks jääb küsimus, kuidas on Jumis saanud kanduda teistesse läänemeresoome ning lisaks mordva ja mari keeltesse. Soome Jumi puhul on seos kaugemate sugulaskeelte Jumoga usutav.

Keelelise distributsiooni seisukohast sobivad kõik seletused, mis lähtuvad tüvedest (olgu need siis oma või laenatud), mis on olnud kasutusel oletataval läänemeresoome ja mordva ning mari ühtsuse perioodil. Eelajaloolise periodiseeringu terminites vastab sellele umbes 1000-aastane periood (ligikaudu 1900-900 eKr), mil seoses kliima jahenemisega toimus ka kuivenemine ning veeteede kokkutõmbumine. Laialdastest territooriumidest ning neile vesitsi ligipääsust sõltuvate soome-ugri kütt-korilaste arvukus vähenes ning eelistatud seisundis olid hõimud, kes olid varasemast kontaktist indo-iraanlastega omandanud karjapidamise/piimanduse ja põllunduse oskused ning transpordivahendid liikumiseks maad mööda (hobune, härjavanker). Hulk laialeheliste puude nimetusi sellest ajast reedab, et asustati piirkonda, kus need olid esindatud. Keelekontaktide mõttes võis alata suhtlemine mingit balti keeltele eelnevat keelekuju kõnelenud hõimudega (vt täpsemalt Vainik: 2014). Sellel perioodil toimus ka pronksi levik, st kiviaeg asendus pronksiajaga. Pronksi levimist on arheoloogid omakorda seostanud indo-iraani kultuurist alguse saanud kindlustatud asulate levikuga (vt Lang 2013; Parpola 2012). Püsivate matmispaikade (kivikalmed) järgi on oletatud, et vähemasti Eesti aladel vastas pronksiaja põllumajanduslikule kultuurile ideoloogiliselt teatud sorti kollektiivsus ja esivanemate kultus, mida ühiskonna eliit sooritas matmisriitustena ning hilisema põletatud surnuluudega manipuleerimisena (Jonuks 2009: 206-214).

Kui lähtuda kirjeldatud pronksiaegsest kultuurilis-majanduslikust ja ideoloogilisest taustast, oleme valiku ees: kas uskuda, et jumala mõiste leiutasid metsas hulkuvad kütt-korilased taevasse vaatamise teel ('taevakaas', 'nägu', 'müristamine') või, et seegi sõna oli üle võetud ühises paketis karjakasvatajatest (proto-)indoiraanlastelt koos muude religioonimõistetega (taevas < *jumal', tõotama, peied, mana, marrask)? Võimalust, et tüve jum- näol on tegu indo-iraani 
laenuga, on oletanud ka teised (nt Koivulehto 1999: 228). Sel puhul on aga lähteks pakutud rekonstrueeritud tüve *diyumna, mille sanskriti vaste dyumān on tähendanud 'taevalik, kirgas, särav'. Selline arutluskäik möönab sõnatüve laenulisust, kuid peab mõiste semantiliseks (ja kogemuslikuks) lähtekohaks ikkagi taevasse vaatamist. Asjaolu, et selle epiteediga on Põhja-Indias välja kujuneneud vedade religioonis kirjeldatud äikesejumal Indrat (Koivulehto 1999: 228) ei tee seda veel kuigi veenvaks jumala mõiste semantiliseks lähtekohaks läänemere-mordva-mari keeli kõnelenud rahvaste seisukohalt. Seda eriti, kui arvesse võtta hõimudevaheliste kontaktide laadi pronksiajal (Vainik 2014).

Põhjendatum tundub oletada, et lähteallikaks on ikkagi tüvi (protobalti *jum-, alg-indoeuroopa *yem-) mis on tähendanud kaksikuid (ja veel algsemalt 'kokku köitmist'), ning mille vasted on erinevate indo-euroopa jumaluste nimed (India Yama, Avesta Yima, Norra Ymir). Näib, et indo-euroopaliku elu ja surma dialektika adumise juurde on algusest peale vältimatult kuulunud surma(jumaluse) lepitamise ja ohverdamise rituaalid. Selliste toimingute vaatlemine ja matkimine võib olla üheks mõeldavaks kontekstiks, kus religioosset sõnavara on laenatud. Näiteks on arheoloogid kirjeldanud indo-iraani ülikute mastaapseid matusepidustusi, mis kulgesid põhjalike söömingute ja jootudega (Anthony 2007). Need avaldasid kindlasti muljet soome-ugri külalistele. Indoiraani surnuteaustamise kultuuri kajastusena on eesti keeles säilinud sõnad näiteks ka peied, mana ja marrask. ${ }^{27}$

Siinse artikli autor ei ole pädev otsustama, kas laenatud tüvest jum- võidi sõna jumal(a) tuletada pigem genuiinse kohasufiksiga -l(a) või moodustati liitsõna jum+ala. Igatahes pole võimatu, et sõna varasemaks tähenduseks on olnud kohatähendus, näiteks '(esivanemate/hõimu) matmispaik', 28 ja sellega on seostunud teatud rituaalsed praktikad (näiteks ühised mälestussöödud ja -joodud, ohverdamised). Nii või teisiti on käesolev arutlus viinud meid juba algselt Uku Masingu pakutud surnutega seotud tähenduse juurde. Tõsi küll, arutluskäik on olnud täiesti erinev, ja siinses artiklis ei väideta, nagu oleks jum-tüvi otseselt tähendanud 'surnut' (vrd Masing 1998: 43). Loogilisemad tunduvad seletused, et hauarituaalidega on kas rõhutatud hõimu sümboolset 'kokku köitmist' surnud esivanematega ja/või on matmisala juba olnud teatud kindlama esivanemaid ning elu ja surma kokkukuuluvust sümboliseeriva jumaluse protektsiooni all.

Keerulisema tuletamise (või liitsõnamoodustuse) ning metonüümset tähendusnihet конт $\rightarrow$ vASTUTAV ISIK eeldava versiooni kõrval võiks välja pakkuda ka lihtsama, mis ei eelda sõnamoodustust ega seost surnute ja matustega ning mis omal kombel lubab jumalat seostada ka taevaga. Nimelt on võimalik, et liikuva varanduse ${ }^{29}$ kokkuahnitsemisele orienteeritud indo-iraani karjakasvatajad (Anthony 2007) palusid oma taevajumalat (Deiwos), et see annaks karjale 
järelkasvu paarikaupa (vaste sanskriti yamala 'paarikaupa, kahekordselt', läti jumala 'paks emane'). Kuuldes pealt fraasi "Yamala, Deiwos!" '(Anna) topelt, Jumal!'30 ja võib-olla ka, nähes pealt mõnda taeva suunas orienteeritud liigutust, võisid antud kultuurikontekstis mitte kodus olevad soomeugrilased fraasi eksitõlgendada, nagu väidetaks, et "jumal asub taevas!". ${ }^{31}$ Sellist eksitõlgendust kohe päris kindlasti keegi korrigeerima ei hakanud, sest indo-iraani ühiskond oli kastiühiskond suletud preestrite seisusega (Anthony 2007). Ehkki soomeugri infiltrantidel ja kultuurivahetajatel ei olnud lootust tõusta preestriseisusse ega täpselt teada saada religioonimõistete sisu, võisid nad ühiskonnas toimuvat usutavasti siiski kõrvalt jälgida ja hiljem omakeskis kopeerida. Viimati pakutu on muidugi samuti vaid üks võimalikke seletusi selle kohta, kuidas meie kauged esivanemad jumala-sõna saada võisid. Möönan, et see seletus on üsna ootamatu ja võib-olla alguses mitte kuigi kergesti aktsepteeritav. Loogikat on selles aga vähemalt samapalju kui varasemates allikates väljapakutud versioonides.

Olukord, kus sõna/tüvi on laenatud ilma selle sisu kuigi täpselt teadmata, seletab, miks ideoloogilis-religioossesse mõistesüsteemi kuuluvad sõnad ja tüved on küll edasi kantud, kuid nende tähendusi on sobitatud enda kujunevate religioossete arusaamadega ja vajadustega. Näiteks võidi jum-tüvelist nähtust hakata pidama panteistlikuks maailmavaimuks, elujõuks, personifitseeritud viljakusjumaluseks, abistajaks, loojaks ja miks ka mitte taevaseks üliolendiks, kui sellise mõiste järele tekkis vajadus.

Kõike kokkuvõttes osutusid päritoluversioonid, mis käsitlevad jumV-tüve omasõnana, käesoleva artikli autori meelest põnevaks, kuid veenvuselt nõrgemaks. Eelkõige just keeleline ja geograafiline distributsioon ning vastete olemasolu mittesugulaskeelte mütoloogilises sõnavaras teeb usutavamaks pigem iidse laenulisuse. Arheoloogiakirjandusest pärit taustainfo laseb paremini mõista ajastu olusid ja kultuurikontakte, kuid jätab siiski lahtiseks laenamise täpsed asjaolud - kas jumal on olnud reaalse esivanematekultusega seoses olev mõiste või siis võõrast kultuurist eksitõlgenduse teel üle võetud sõna.

\section{Tänuavaldused}

Artikli varasema versiooni kommenteerimise eest tänan Udo Uibot ja kaardigraafika eest Pille Tomsonit. 


\section{Lühendid}

$\mathrm{E}=$ Matthias Johann Eiseni rahvaluulekogu Eesti Kirjandusmuuseumis

EÜS = Eesti Üliõpilaste Seltsi rahvaluulekogu Eesti Kirjandusmuuseumis

$\mathrm{H}=$ Jakob Hurda rahvaluulekogu Eesti Kirjandusmuuseumis

SKVR = Suomen Kansan Vanhat Runot

\section{Kommentaarid}

1 Uurimust on osaliselt toetanud sihtfinantseeritav teadusteema SF0050023s09.

2 http://www.folklore.ee/regilaul/andmebaas/ (24. oktoober 2014).

3 Päringuvormelis jumal* esinev tärn (*) tähendab seda, et otsitakse suvaliselt jätkuvat märgijada.

${ }^{4}$ E $64174<$ Kolga-Jaani khk. Värsinäidete kirjaviis on siin ja edaspidi jäetud muutmata.

5 Väljendiga jumala kukk võidakse muidugi viidata tuulelipule kirikutornis (ja seega kristlikule müüdile), kuid samahästi võib konteksti põhjal (paralleelvärssides hüljes ja luik) oletada seost muinaspõhja mütoloogiaga. Üheks kandidaadiks võiks olla kukk Gullinkambi ‘kuldne kamm', keda on kujutatud istuvat maailmapuu Yggdrasili tipus (http://en.wikipedia.org/wiki/Gullinkambi - 25. oktoober 2014).

6 On erutav mõelda, et see müüt on võinud saada alg- või järeltõuke aastal 536 asetleidnud klimaatilisest katastroofist, mil põhjapoolkera taevas kattus kas vulkaanilise tuha tõttu või mingil muul põhjusel nii paksu pilvekattega, et kliima jahenes tuntavalt, saagid ikaldusid ja inimesed, kes olenesid üksnes põllumajandusest, hukkusid massiliselt. Nende hulgas, kes ellu jäid, oletatakse religioossuse tõusu, vähemasti Skandinaavias on pärast seda sündmust täheldatud väärismetallist esemete soodesse ja järvedesse ohverdamise suurenemist (Tvauri 2012).

7 Eesti murrete sõnaraamat, käsikiri veebis http://www.eki.ee/dict/ems/vihikud/06.pdf (24. oktoober 2014).

8 Linnainimesele: ots laotakse vahelduvate suundadega, et anda riidale stabiilsust.

9 Igaüks, kes on telliseid virna ladunud, teab, et ka seda tuleb teha vahelduvate suundadega, et anda virnale stabiilsust.

${ }^{10}$ Kasutatud veebiversiooni: http://starling.rinet.ru/cgi-bin/response.cgi?root=config\&m orpho $=0 \&$ basename $=\backslash$ data $\backslash$ ie $\backslash$ vasmer $(24$. oktoober 14$)$.

${ }^{11}$ Ilmselt on just see kirjakoht olnud ajendiks lokaliseerida toda püha hiit Eba-vere mäele, justnagu oleks tol mäel midagi pistmist vere puudumisega.

12 http://www.cl.ut.ee/korpused/segakorpus/index.php?lang=et (24. oktoober 2014).

${ }^{13}$ Servama - 'rüüpama, üle serva jooma' (murd).

14 Tänapäeval arvatakse, et värkes õhus liikumine annab tervist ja parandab jumet, muiste tundub olnuvat teisiti.

${ }^{15}$ Ka kurnama viitab vedelikule, st elumahladele. 
${ }^{16}$ Soome vikipeedia http://fi.wikipedia.org/wiki/Jumi (24. oktoober 2014) ja sealne viide Otava 1968, osa 3: 1680.

17 Soome runolaulude andmebaas vt http://dbgw.finlit.fi/skvr/ (24. oktoober 2014).

18 Soome vikipeedia http://fi.wikipedia.org/wiki/Jumi (13 juuni 2014).

19 Tõenäoliselt viimasest võimalusest lähtudes seostatakse selle tüvega Põhja-Lätis paikneva Jumara (Ümera) jõe nime. Seda peetakse motiveerituks kahe jõe - Gauja ja Jumara (Koiva ja Ümera) - ühinemiskohaga (Karulis 1992: 361).

${ }^{20} \mathrm{http} / / /$ piereligion.org/jumis.html (24. oktoober 2014) ja sealsed viited läti rahvalauludele (Švābe jt 1952-1956).

${ }^{21} \mathrm{http}$ ://starling.rinet.ru/ (18. november 2014).

${ }^{22} \mathrm{http} / / /$ starling.rinet.ru/cgi-bin/response.cgi?single $=1 \&$ basename $=\% 2 \mathrm{fdata} \% 2 \mathrm{fie} \% 2 \mathrm{fpi}$ et\&text_number $=++1375 \&$ root=config.

${ }^{23}$ Selline parvelaadne moodustis on võinud olla kasutusel algelisema transpordivahendina või ka hõimude omavahelise kauplemise kohana (vrd tähendus 'laplaste kogunemise koht kalasaaduste müügiks').

${ }^{24}$ Briti entsüklopeedia võrguversioon http://www.britannica.com/EBchecked/topic/651461/ Yama (24. oktoober 2014).

${ }^{25}$ Pronksiaegsed kivikirstkalmed, mis esindavad esivanemate kultust ja kollektiivhinge kontseptsiooni, on Eestiski olnud orienteeritud just lõunasuunas, seda on aga seostatud päikesekultusega üldisemalt ja mitte mingi konkreetsema jumalusega (vt Jonuks 2009).

${ }^{26}$ EES seostab seda eesti sõnaga jama 'ühenduskoht'.

${ }^{27}$ Sõna marrask 'naha õhuke pindmine kiht' on seostatud algindoiraani tüvega * $m r t a ́$-s 'surnud' (EES). Võimalik, et selle sõna laenamine oli relevantne eelkõige tingituna tavast puhastada surnuluud nahast ja pehmetest kudedest, näiteks põletamise, keetmise või ka kraapimise teel.

${ }^{28}$ Samas leidub vähemalt eesti keeles matmispaikade kohta mitmeid sünonüüme (haud, kalm, kääbas, vare, surnuaed, kalmistu), ja ükski neist ei lõpe -la sufiksiga. Küll aga teevad seda mitmed mütoloogilised surnuteriikide nimetused nagu Toonela, Manala, Hiiela.

${ }^{29}$ Nimetus *peku- 'kari' (Anthony 2007 viide Benveniste 1973: 40-51) on kahtlustäratavalt sarnane Setu viljakusjumalus Pekole.

${ }^{30}$ Indo-iraanlased võisid mõistagi ka lubada Deiwosele topeltohvrit, osutada suuremeelsust kaupade eest topelt tasumisega või hoopis vanduda Deiwose nimel vaenlasele kahekordset kättemaksu vmt.

${ }^{31}$ Loogika on siin samasugune kui Taarapita saamisel vormelist Taara pitka! 'Taara on suur' (Sutrop 2001). 


\section{Internetiallikad}

Alg-indo-euroopa religiooni koduleht http://piereligion.org/ (28. oktoober 2014).

Briti entsüklopeedia võrguversioon http://www.britannica.com/ (28. oktoober 2014).

Eesti keele koondkorpus http://www.keeletehnoloogia.ee/projektid/koondkorpus (28. oktoober 2014).

Eesti keele seletav sõnaraamat http://www.eki.ee/dict/ekss/ (28. oktoober 2014).

Eesti murrete sõnaraamatu käsikiri http://www.eki.ee/dict/ems/vihikud/06.pdf(28. oktoober 2014).

Eesti regilaulude andmebaas http://www.folklore.ee/regilaul/avaleht/ (28. oktoober 2014).

Etümoloogilised andmebaasid veebis http://starling.rinet.ru/cgi-bin/main.cgi?root=config (28. oktoober 2014).

Nimisõna poeetilised sünonüümid http://www.keelevara.ee/login/?d=poeetilised _ synonyymid (28. oktoober 2014).

Soome runolaulude andmebaas http://dbgw.finlit.fi/skvr/ (28. oktoober 2014).

Soome Wikipeedia http://fi.wikipedia.org/wiki/ (28. oktoober 2014).

Valter Langi loengu "Kuidas, miks ja millal said meist läänemeresoomlased?" videosalvestus:http://www.postimees.ee/2595632/millal-said-eestlastestlaanemeresoomlased-vaata-videoloengut (28. oktoober 2014).

Vasmeri sõnaraamat: http://starling.rinet.ru/cgi-bin/response.cgi?root=config\&morpho $=0 \&$ basename $=\backslash$ data $\backslash$ ie $\backslash$ vasmer $(28$. oktoober 2014$)$.

\section{Kirjandus}

Anthony, David W. 2007. The Horse, the Wheel, and Language. How Bronze-Age Riders from the Eurasian Steppes Shaped the Modern World. Princeton: Princeton University Press.

Benveniste, Émile 1973 [1969]. Indo-European language and society. London: Faber \& Faber.

EES = Metsmägi, Iris \& Sedrik, Meeli \& Soosaar, Sven-Erik (koost ja toim) 2012. Eesti etümoloogiasõnaraamat. Tallinn: Eesti Keele Sihtasutus.

EKSS = Langemets, Margit \& Tiits, Mai \& Valdre, Tiia \& Veskis, Leidi \& Viks, Ülle \& Voll, Piret (toim) 2009. Eesti keele seletav sõnaraamat 1-6 (2., täiendatud ja parandatud trükk). Tallinn: Eesti Keele Sihtasutus (http://www.eki.ee/ dict/ekss/ - 27. oktoober 2014).

EMS = Haak, Anu \& Juhkam, Evi \& Must, Mari \& Neetar, Helmi \& Niit Ellen, \& Oja, Vilja \& Ross, Eevi \& Viires, Helmi (koost) 1997. Eesti murrete sõnaraamat II 6 J-KTallinn: Eesti Keele Instituut. 
Jonuks, Tõnno 2009. Eesti muinasusund. Tartu: Tartu Ülikooli Kirjastus.

HLK 1993 = Henriku Liivimaa Kroonika. Tallinn: Olion.

Karulis, Konstantīns 1992. Latviešu etimoloǵijas vārdnīca I. Rīga: Avots.

Koivulehto, Jorma 1999. Varhaiset indoeurooppalaiskontaktit: aika ja paikka lainasanojen valossa. Fogelberg, Paul (toim). Pohjan poluilla: Suomalaisten juuret nykytutkimuksen mukaan. Helsinki: Societas Scientarum Fennica, lk 207-236.

Kulmar, Tarmo 2006. Taevasest üliolendist usundilooliselt ja muinaseesti aineses. Mäetagused 30, lk 17-32 (doi: 10.7592/MT2005.30.kulmar).

Lang, Valter 2013. Kuidas, miks ja millal said meist läänemeresoomlased? Tartu ülikoolis rahvusteaduste loengusarjas 14.11.2013 peetud loeng. Videosalvestus veebis: http://www. postimees.ee/2595632/millal-said-eestlastest-laanemeresoomlased-vaata-videoloengut (27. oktoober 2014).

Lakoff, George \& Johnson, Mark 2011. Metafoorid, mille järgi me elame. Tallinn: Tallinna Ülikooli Kirjastus.

Laurinkienè, Nijolè 2004. Kujutelm taevast ja päikese loomise motiivid balti mütoloogias. Mäetagused 24, lk 91-98 (doi: 10.7592/MT2003.24.laurinkiene).

Loorits, Oskar 1949. Grundzüge des estnischen Volksglaubens I. Skrifter Utgivna av Kungl. Gustav Adolfs Akademien för Folklivsforskning 18. Lund: Blom.

Loorits, Oskar 1990. Eesti rahvausundi maailmavaade (3. trükk). Tallinn: Perioodika.

Metsmägi, Iris \& Sedrik, Meeli \& Soosaar, Sven-Erik 2012. Eesti kirjakeele tüvevara päritolu arvudes. Keel ja Kirjandus 5, lk 313-332.

Masing, Uku 1995. Eesti usund (2., parandatud trükk). Tartu: Ilmamaa.

Oinas, Felix 1973. The Baltic Background of Balto-Finnic Folklore. Ziedonis, Arvids \& Puhvel, Jaan \& Šilbajoris, Rimvydas \& Valgemäe, Mardi (toim). Baltic Literature and Linguistics. Publications of the Association for the Advancement of Baltic Studies. Columbus, Ohio: The Ohio State University, lk 109-118.

Oinas, Felix 1981. Jumi - A fertility divinity. Journal of the Folklore Institute 18, lk 69-89.

Oinas, Felix 2004. Soome-eesti ja balti rahvaluule suhetest. Uurimusi Kalevipojast [võrguteavik]. Tartu: Eesti Kirjandusmuuseumi folkloristika osakond (http://www. folklore.ee/rl/folkte/myte/kalev2/oinas_17.html - 24. oktoober 2014).

Otava 1960-1965 = Ravila, Paavo \& Havu, Ilmari (toim). Otavan Iso Tietosanakirja (Encyclopaedia Fennica) 1-10. Helsinki: Otava.

Parpola, Asko 2012. The problem of Samoyed origins in the light of archaeology: On the formation and dispersal of East Uralic (Proto-Ugro-Samoyed). Per Urales ad Orientem. Iter polyphonicum multilingue. Festskrift tillägnad Juha Janhunen på hans sextioårsdag den 12 februari 2012. Suomalais-Ugrilaisen Seuran Toimituksia = Memoires de la Societe Finno-Ougrienne 264, lk 287-298 (http://www.sgr.fi/sust/sust264/sust264_parpola.pdf_ 27. oktoober 2014). 
Peegel, Juhan 2004. Nimisõna poeetilised sünonüümid eesti regivärssides. (Teine, läbi vaadatud ja ühtlustatud trükk.) Eesti Keele Instituut, Eesti Teaduste Akadeemia, Emakeele Selts. Tallinn: Eesti Keele Sihtasutus.

Pokorny, Julius 2002. Indogermanisches etymologisches Wörterbuch. Tübingen-Basel: A. Francke Verlag.

Puhvel, Jaan 1996. Võrdlev mütoloogia. Tartu: Ilmamaa.

Põldvee, Aivar 2013. Vanemuise sünd. Lisandusi eesti pseudomütoloogia ajaloole. Tuna. Ajalookultuuri ajakiri 1 (58), lk 10-31.

Saareste, Andrus 1958-1979. Eesti keele mõisteline sõnaraamat. Dictionnaire analogique de la langue estonienne: Avec un index pourvu des traductions en français I-IV \& Indeks. (= Eesti Teadusliku Seltsi Rootsi väljaanne 3.) Stockholm: Vaba Eesti.

Sarmela, Matti 1994. Suomen perinneatlas: Suomen kansankulttuurin kartasto 2. Atlas of finnish ethnic culture 2. Folklore. Suomalaisen Kirjallisuuden Seuran toimituksia 587. Helsinki: Suomalaisen Kirjallisuuden Seura.

Sutrop, Urmas 2001. Taarapita - eestlaste suur jumal. Mäetagused 16, lk 7-38 (doi: 10.7592/MT2001.16.sutrop).

Sutrop, Urmas 2004a. Eesti keele maailmapildist: meel, hing ja vaim. Mäetagused 24, lk 99-108 (doi: 10.7592/MT2003.24.sutrop).

Sutrop, Urmas 2004b. Oletatav paganlike eestlaste puust jumalakuju Oleviste raamatukogus. Mäetagused 27, lk 127-134 (doi: 10.7592/MT2004.27.sutrop).

SSA = Itkonen, Erkki \& Kulonen, Ulla-Maija (toim). Suomen sanojen alkuperä. Etymologinen sanakirja (1992-2000). Suomalaisen Kirjallisuuden Toimituksia 556. Helsinki: Suomalaisen Kirjallisuuden Seura \& Kotimaisten kielten tutkimuskeskus.

Sweetser, Eve 1990. From Etymology to Pragmatics: The Mind-body Metaphor in Semantic Structure and Semantic Change. Cambridge: Cambridge University Press.

Švābe, Arveds \& Straubergs, Kārlis \& Hauzenberga-Šturma, Edīte (toim) 1952-1956. Latviešu tautas dziesmas (volumes I-XII). Copenhagen: Imanta.

Tedre, Ülo 1998. Rahvalaulud. Viires, Ants \& Vunder, Elle (koost ja toim). Eesti rahvakultuur.Tallinn: Eesti Entsüklopeediakirjastus, lk 548-564.

Tvauri, Andres 2012. The Migration Period, Pre-Viking Age, and Viking Age in Estonia. Tartu: Tartu University Press.

Uibo, Udo 2014. Sõnalood. Etümoloogilisi vesteid. Tallinn: Tänapäev.

Vainik, Ene 2013. Mida teevad mõtted, kui nad mõlguvad? Emakeele Seltsi aastaraamat 58 (1). lk 233-264 (doi: 10.3176/esa58.12).

Vainik, Ene 2014. Early emotional contacts with the Indo-Europeans. ESUKA JEFUL 5(2), lk 139-167.

Vare, Silvi 2012. Eesti keele sõnapered. Tänapäeva eesti keele sõnavara struktuurianalü̈̈s. I-II. Tallinn: Eesti Keele Sihtasutus. 
Vasmer, Max 1958. Russisches etymologisches Wörterbuch. 3 Bde. Heidelberg: Carl Winter.

Vilkuna, Kustaa 1974. Jumihäät. Kalevalaseuran Vuosikirja 54. Helsinki, lk 485-500.

Vuorela, Toivo 1979. Kansanperinteen sanakirja. Porvoo, Helsinki: WSOY.

Õim, Asta 2000. Fraseoloogiasõnaraamat (Teine, täiendatud ja parandatud trükk). Tallinn: Eesti Keele Sihtasutus (http://www.eki.ee/dict/fras/ - 28. oktoober 2014).

Wiedemann, Ferdinand J. 1973 [1893]. Eesti-saksa sõnaraamat. Estnisch-Deutsches Wörterbuch (Neljas, muutmata trükk teisest, Jakob Hurda redigeeritud väljaandest). Tallinn: Valgus.

\section{Summary}

\section{Tracing Back the Word jumal ('God')}

Ene Vainik

Keywords: Estonian, etymology, folk belief, loans, semantics, theonyms

The paper discusses the origins of the Estonian word jumal ('God'). First, it summarises the versions proposed by previous treatises, and thereafter the linguistic material of Estonian runo songs is analysed in order to detect variations in its usage, pointing to the possible pre-Christian meaning of the word. The body of the paper consists of presenting and discussing the alternative stems that the word jumal could be derived from. Among them are some appellatives (jumm/juma 'log'; jumi/jume 'colour of the face') as well as proper names of the mythological creatures of the neighbouring countries (Finnish Jumi and Latvian Jumis) and the name of the Indo-European divine twin (Yemo).The linguistic and geographical distribution of the term as well as the background information obtained from archaeology suggest that the latter version fits the best. In the following a somewhat more extended summary of the abovementioned sections of the paper is presented.

The previous treatises agree that the term jumal is of genuine origin. It is considered to be a derivative term consisting of the stem jumV (the last vocal varying between $(a / e / i)$ and of a suffix (-l-). They disagree on its proposed original meaning ('cover', 'face', 'sound of thunder', 'good', 'essence', 'shivering', 'dead body') and on what the function of the suffix has been. There are also different opinions on whether the supposed supreme being has been of "heavenly" kind or it could have been located elsewhere.

The analysis of the context in which the term jumal was used in the runo songs revealed that besides the usages in the Christianity-related contexts (co-located with Jeesuke ('Jesus') and Mari ('Mary')) there were other uses where it omitted such a company. Among them were the stereotypical phrases and addresses for help and the pantheistic nature-related usages (in connection with wind, trees and light). There were also some references to the genuine Baltic-Finnic mythological heritage (the God-Smith, 
the 'golden trace of god', etc.) and some usages that could be cultural influences from the neighbours.

Tracing back the dialectal stem jumm/juma ('log') reveals its cognate in ancient Russian 'connected rafts; catamaran'. The wood-related origin of the word jumal is considered semantically motivated (the wooden statues of gods being the link between the ideological content and the material), but the stem as the actual origin of jumal is questionable because of its presence not only in the Baltic-Finnic languages but also in Mordvinic and Mari. The stem jumi/jume ('colour of the face') appeared to be used in different meanings mainly in the archaic runo songs, indicating 'vital force' and 'mental force'. These meanings fit perfectly with the Estonians' animistic worldview in general and their obsession with the vital force noticed by the earlier authors. Also, the usage of the term reveals that metonymy (PALENESS STANDS FOR PHYSICAL/MENTAL WEAKNESS) and metaphors (e.g. VITAL/MENTAL FORCE IS LIQUID, VITAL/MENTAL FORCE IS A PERSON) have been at work. Derivation of the notion of jumal from such a concept seems highly probable. However, the abstract meanings are only locally distributed in a part of southern Estonia while the word jumal(a) is known in the Baltic-Finnic languages and its cognates also in Mari and Mordvinic.

In the Finnish heritage there was a mythological creature called Jumi. He appeared as double-faceted: causing of sudden diseases was attributed to him, and at the same time he was the fertility deity, worshipped in a special type of play-weddings. Jumi has been referred to as the Finno-Ugric pantheistic "spirit of the world" having a cognate at least in Mari (Jumo). Derivation of the appellative jumal from such a proper name seems highly probable.

In Latvian there is a word jumi-s (f. juma-, njume-) ('double fruit'), and its supposed derivative jumala ('fat female'). Historically, there has been a fertility deity called Jumis in the Baltic pantheon. Derivation of the appellative jumal ('god') from the borrowed proper name of the fertility deity also seems probable. In addition, there is a possibility that the whole word jumala has been borrowed. Again, the linguistic and geographic distribution of the term makes this particular version of borrowing somewhat questionable.

The Latvian Jumis is etymologically connected to the Indo-European divine twin Yemo, which has cognates in the creation myths of several Indo-European cultures and his role has been to symbolise the connection of living people to the dead ancestors. The original meaning of the stem is believed to be 'to bind together'. Purely linguistic evidence leaves it uncertain whether this could be the actual origin of the term jumal, but the word has been borrowed to the Finno-Ugric languages at least once (the Sami juomek 'twin').

The linguistic distribution (cognates in Mari and Mordvinic) suggests that the stem Jum must have been coined or borrowed during the prehistoric period 1900-900 BC. At that time bronze spread from the East to the West, and together with it the fortified settlements similar to the Indo-Iranian ones. The herding and cultivating economy produced more food than hunting and gathering, thus giving an advantage to the tribes who had changed their economy. The archaeological evidence (types of graves) in Estonia reveals a collectivist mentality and a cult of ancestors. Therefore, within the whole economic, cultural and ideological package, borrowing of the name of the deity of dead ancestors 
Yemo $\rightarrow$ Jum seems highly probable. There are several other religion-related Indo-Iranian loanwords in Estonian (taevas 'heaven' <*'god', peied 'wake', mana- 'spell; underworld', marrask (of skin) 'dead'). The original ancestor-related meaning of the name/stem jum, however, has been reinterpreted according to the evolving needs of the Finno-Ugric speaking societies: it could refer to the pantheistic "spirit of the world", the fertility deity, the life force, the ultimate helper, the creator, the heavenly supreme being, etc. 